\title{
Analysis Relationship of Imported Rice with Rice Production, Imported and Domestic Rice Prices with VECM
}

\section{Analisis Hubungan Impor Beras Dengan Produksi Beras, Harga Beras Impor dan Domestik Dengan VECM}

\author{
Abyan Rai ${ }^{1 *}$, Sasmito Hadi Wibowo ${ }^{2 *}$
}

\begin{abstract}
Rice is the main food for most Indonesians. With much natural resources, Indonesia can naturally fulfill its own rice consumption needs. However, Indonesia actually relies on imports to meet consumption needs. Even Indonesia continues to import while rice production is volatility surplus to maintain domestic rice prices. Based on these problems, this study aims to analyze the relationship of volume of imported rice with rice production, domestic rice prices, and prices of imported rice. The method used is descriptive analysis and Vector Error Correction Model (VECM). In the long-term, rice production and domestic rice prices have significant effect on Indonesia's rice import volume. In short-term, rice production and domestic rice prices have significant effect on Indonesian rice import volume. The results of the causality test show that there is a two-way relationship between Indonesian rice import volume and Indonesian production rice. Meanwhile, a one-way relationship occurs when imported rice volumes influenced by prices of domestic rice.
\end{abstract}

Keywords: Rice imports, VECM, causality

\begin{abstract}
Abstrak
Beras merupakan makanan pokok bagi sebagian besar masyarakat Indonesia. Dengan sumber daya alam yang melimpah, Indonesia sewajarnya bisa memenuhi kebutuhan konsumsi berasnya sendiri dari hasil produksi. Akan tetapi, Indonesia juga bergantung dari impor untuk memenuhi kebutuhan konsumsi. Bahkan Indonesia tetap melakukan impor disaat produksi beras sedang surplus untuk menjaga harga beras domestik. Berdasarkan masalah tersebut, penelitian ini bertujuan untuk menganalisis hubungan volume impor beras dengan produksi beras, harga beras domestik, dan harga beras impor. Metode yang digunakan adalah analisis deskriptif dan Vector Error Correction Model (VECM). Dalam jangka pendek maupun jangka panjang, produksi beras dan harga beras domestik berpengaruh signifikan terhadap volume impor beras Indonesia. Hasil uji kausalitas menunjukkan bahwa terjadi hubungan dua arah antara volume produksi beras Indonesia. Sedangkan, hubungan satu arah terjadi ketika volume impor beras dipengaruhi harga beras domestik.
\end{abstract}

Kata kunci: Impor beras, VECM, kausalitas

\footnotetext{
*Badan Pusat Statistik

Email: ${ }^{1}$ abyan.rai@bps.go.id, ${ }^{2}$ wibowo100@gmail.com
} 


\section{Abyan Rai , Sasmito Hadi Wibowo}

\section{Pendahuluan}

Indonesia merupakan negara yang diberkahi dengan sumber daya alam yang melimpah. Hal tersebut menjadikan Indonesia sebagai salah satu negara dengan keanekaragaman hayati sangat besar (mega biodiversity) di dunia setelah Brazil [8]. Kekayaan sumber daya alam Indonesia menjadi modal yang sangat penting untuk mencukupi kebutuhan masyarakat Indonesia.

Swasembada dalam hal konsumsi sudah merupakan hal yang sewajarnya terjadi di Indonesia mengingat sumber daya alam yang dimiliki sangat memadai. Apabila pengelolaan terhadap sumber daya alam Indonesia yang melimpah dilaksanakan dengan baik, kebutuhan masyarakat Indonesia terutama kebutuhan untuk konsumsi akan tercukupi. Dengan demikian, kemandirian untuk memenuhi kebutuhan konsumsi masyarakat atau swasembada bisa terwujud.

Beras adalah barang konsumsi yang merupakan makanan pokok warga negara Indonesia secara umum. Bahkan, pola pikir warga negara Indonesia adalah bahwa belum makan kalau belum makan nasi [5]. Konsumsi beras masyarakat Indonesia sangat tinggi mencapai dua kali lipat konsumsi beras dunia [1]. Tingginya konsumsi beras diharapkan mampu tercukupi oleh produksi beras dalam negeri. Sehingga pemerintah tidak memerlukan impor beras dari negara lain.

Indonesia merupakan salah satu negara teratas yang mampu menghasilkan produksi padi dengan angka yang tinggi. Data FAO menunjukkan bahwa Indonesia berada di posisi ketiga sebagai produsen padi terbesar di dunia tahun 2016 dengan volume produksi mencapai 81,38 juta ton. Indonesia hanya kalah dari negara Tiongkok dan India yang memiliki volume produksi padi secara berturut-turut mencapai 214,43 juta ton dan 168,5 juta ton pada tahun 2016. Besarnya angka produksi padi tersebut diharapkan mampu mencukupi konsumsi beras masyarakat Indonesia sekaligus menjaga persediaan cadangan stok beras di Indonesia.

Di sisi lain, data FAO juga menunjukkan bahwa volume impor beras Indonesia mencapai 1,282 juta ton di tahun 2016. Angka tersebut menempatkan Indonesia sebagai negara kedua dengan volume impor terbesar dari lima negara produsen beras terbesar di dunia pada tahun 2016. Impor beras Indonesia hanya berada di bawah Tiongkok dan jauh lebih besar dari India yang hanya mengimpor 995 ton beras di tahun 2016.

Kepala BPS, Suhariyanto menyatakan bahwa produksi beras Indonesia mengalami surplus terhadap konsumsi beras nasional dengan nilai sebesar 2,85 juta ton di tahun 2018 [12]. Meskipun demikian, data Comtrade menunjukkan bahwa Indonesia tetap melakukan impor beras sebesar 2,25 juta ton di tahun 2018. Hal ini menunjukkan bahwa ketergantungan Indonesia terhadap impor beras sangat tinggi. Bahkan, Indonesia tetap melakukan impor beras dalam kondisi surplus produksi.

Tingginya volume impor beras Indonesia bisa disebabkan oleh harga beras impor itu sendiri. Harga beras impor yang relatif lebih murah dari harga beras domestik semakin membuat Indonesia kesulitan untuk lepas dari status sebagai negara importir beras [14]. Murahnya harga beras impor memicu Indonesia untuk secara periodik melakukan impor beras. Seiring dengan meningkatnya permintaan impor beras, harga beras impor menurun sesuai kaidah hukum permintaan. Hal ini menyebabkan Indonesia semakin terjebak dalam lingkaran ketergantungan impor beras.

Pengendalian volume impor beras juga bisa berdampak pada produksi beras yang dihasilkan pada periode yang akan datang. Ketika produksi beras di pasar cukup dan impor masuk, banjir beras akan terjadi di pasar [2]. Kondisi demikian sangat mungkin untuk membuat harga beras menurun dan membuat petani tidak mau menanam padi lagi akibat harga yang diterima tidak mampu menutupi biaya produksi.

Dampak negatif dari impor beras yang tidak terkontrol juga dapat dirasakan saat stok beras di pasaran kurang untuk mencukupi permintaan beras masyarakat Indonesia dan menyebabkan 


\section{Abyan Rai , Sasmito Hadi Wibowo}

harga menjadi tinggi. Harga beras domestik yang stabil sangat penting mengingat beras merupakan makanan pokok bagi sebagian besar masyarakat Indonesia. Masyarakat berpenghasilan rendah juga termasuk di dalam bagian tersebut yang $25 \%$ dari konsumsinya adalah beras. Sehingga harga beras domestik yang tinggi akan mendorong naik angka kemiskinan. Setiap kenaikan harga beras sebesar 10\%, masyarakat miskin meningkat sebesar 1\%, atau lebih dari dua juta orang [6].

Penelitian mengenai impor beras Indonesia menjadi penting mengingat peran dan dampaknya terhadap pemenuhan konsumsi beras dalam negeri, menjaga kesejahteraan petani agar produksi beras tidak menurun, dan menjaga stabilitas beras domestik. Analisis mengenai hubungan antara impor beras, produksi beras, harga beras impor, dan harga beras di Indonesia juga perlu dilakukan untuk menyusun strategi dalam pengendalian impor beras Indonesia.

Penelitian ini disusun untuk memenuhi kebutuhan analisis hubungan antara impor beras, produksi beras, harga beras impor, dan harga beras di Indonesia. Penelitian ini juga menganalisis pergerakan impor beras, produksi beras, harga beras domestik, dan harga beras impor di Indonesia. Terakhir, penelitian ini bertujuan untuk menganalisis respons dari masing-masing variabel saat variabel yang lain mengalami shock.

Model VAR dikembangkan oleh Sims di tahun 1980 sebagai alternatif dalam pemodelan ekonometrik yang bersifat non struktural yang bersifat tanpa teori [4]. Model VAR memiliki struktur yang lebih sederhana dengan jumlah variabel yang lebih minimalis. Seluruh variabel dalam model VAR adalah variabel endogen dengan variabel eksogennya adalah lag dari seluruh variabel. VAR dibangun untuk variabel yang stasioner dan tidak mengandung tren. Kemudian Engel bersama Granger membangun konsep kointegrasi dan error correction. Kemudian, Johansen dan Juselius mengembangkan konsep VECM sebagai bentuk VAR teristriksi.

Kurangnya dasar teori yang kuat dan penelitian terdahulu untuk menggambarkan hubungan simultan (timbal balik) dari volume impor beras Indonesia dengan produksi beras, harga beras impor, dan harga beras domestik membuat pemodelan dengan VAR/VECM lebih tepat digunakan dibandingkan dengan pemodelan simultan. Model VAR/VECM lebih menguntungkan untuk digunakan dalam penelitian mengingat keunggulan dari model VAR/VECM yang non struktural dan bersifat tanpa teori.

\section{Metodologi}

\subsection{Sumber Data dan Variabel Penelitian}

Penelitian ini dilakukan dengan menggunakan data time series tahunan mulai dari tahun 1990 sampai dengan tahun 2017 di Indonesia. Jumlah observasi dari penelitian adalah 28 observasi atau periode waktu. Periode waktu atau jumlah observasi yang diperoleh sudah cukup optimal untuk melakukan estimasi. Variabel yang akan diteliti adalah variabel volume impor beras Indonesia, total produksi beras Indonesia, harga beras impor, dan harga beras di Indonesia. Seluruh variabel bersumber dari Badan Pusat Statistik.

\subsection{Metode Penelitian}

Untuk menganalisis data, penelitian ini menggunakan dua metode analisis yaitu analisis deskriptif dan analisis data time series yaitu VECM. Data diolah dengan menggunakan Microsoft Excel dan Eviews 8. Berikut adalah langkah-langkah dalam melakukan analisis VECM:

1. Melakukan pengujian stasioneritas dengan uji Phillip-Peron. Lakukan pengujian di level. Saat pengujian di level menunjukan data tidak stasioner, lakukan pengujian pada first difference.

2. Menentukan panjang lag optimum. Lag yang optimum adalah lag yang menunjukan statistik FPE, AIC, SC, dan HQ paling rendah. 


\section{Abyan Rai , Sasmito Hadi Wibowo}

3. Menguji stabilitas VAR dengan menggunakan lag optimum.

4. Menguji kointegrasi Johansen dengan statistik uji Trace dan Maximum Eigen Value.

5. Membentuk persamaan jangka panjang dari volume impor beras Indonesia.

6. Membentuk estimasi persamaan VECM. Berikut adalah persamaan VECM dalam model:

$$
\begin{aligned}
& \Delta \operatorname{Ln} X_{1}=\lambda_{1}+\sum_{i=1}^{p} \alpha_{1 i} \Delta \operatorname{Ln} X_{1_{t-i}}+\sum_{i=1}^{p} \alpha_{2 i} \Delta \operatorname{Ln} X_{2 t-i}+\sum_{i=1}^{p} \alpha_{3 i} \Delta \operatorname{Ln} X_{3 t-i}+\sum_{i=1}^{p} \alpha_{4 i} \Delta \operatorname{Ln} X_{4 t-i}+\alpha_{5 i} \varepsilon_{t-i}+e_{1 t} \\
& \Delta \operatorname{Ln} X_{2}=\lambda_{2}+\sum_{i=1}^{p} b_{1 i} \Delta \operatorname{Ln} X_{1 t-i}+\sum_{i=1}^{p} b_{2 i} \Delta \operatorname{Ln} X_{2 t-i}+\sum_{i=1}^{p} b_{3 i} \Delta \operatorname{Ln} X_{3 t-i}+\sum_{i=1}^{p} b_{4 i} \Delta \operatorname{Ln} X_{4 t-i}+b_{5 i} \varepsilon_{t-i}+e_{1 t} \\
& \Delta \operatorname{LnX} X_{3}=\lambda_{3}+\sum_{i=1}^{p} c_{1 i} \Delta \operatorname{Ln} X_{1 t-i}+\sum_{i=1}^{p} c_{2 i} \Delta \operatorname{Ln} X_{2 t-i}+\sum_{i=1}^{p} c_{3 i} \Delta \operatorname{Ln} X_{3 t-i}+\sum_{i=1}^{p} c_{4 i} \Delta \operatorname{Ln} X_{4 t-i}+c_{5 i} \varepsilon_{t-i}+e_{1 t} \\
& \Delta \operatorname{LnX} X_{4}=\lambda_{4}+\sum_{i=1}^{p} d_{1 i} \Delta \operatorname{Ln} X_{1 t-i}+\sum_{i=1}^{p} d_{2 i} \Delta \operatorname{Ln} X_{2 t-i}+\sum_{i=1}^{p} d_{3 i} \Delta \operatorname{Ln} X_{3 t-i}+\sum_{i=1}^{p} d_{4 i} \Delta \operatorname{Ln} X_{4 t-i}+d_{5 i} \varepsilon_{t-i}+e_{1 t}
\end{aligned}
$$

\section{Dengan:}

$\begin{array}{ll}X_{1} & : \text { Jumlah volume impor beras Indonesia } \\ \mathrm{X}_{2} & \text { : Jumlah produksi beras Indonesia } \\ \mathrm{X}_{3} & \text { : Rata-rata harga beras impor } \\ \mathrm{X}_{4} & : \text { Rata-rata harga beras tingkat konsumen di Indonesia } \\ \varepsilon_{\mathrm{t}-1} & : \text { Error Correction Term } \\ \lambda & : \text { Koefisien intercept } \\ p & : \text { Jumlah lag } \\ e_{t} & : \text { Error }\end{array}$

7. Melakukan uji asumsi normalitas dengan uji Jarque-Bera dan uji asumsi nonautokorelasi dengan uji Lagrange Multiplier.

8. Melakukan analisis persamaan jangka panjang dan VECM dengan uji parsial t.

9. Melakukan uji kausalitas granger untuk menganalisis hubungan sebab akibat antar variabel.

10. Melakukan analisis Impulse Response Function (IRF) dan Forecast Error Variance Decomposition (FEVD) berdasarkan hasil uji kausalitas granger.

\section{Hasil dan Pembahasan}

\subsection{Gambaran Umum Volume Impor Beras Indonesia}

Indonesia pernah mendapatkan capaian prestasi yang membanggakan di tahun 1984. Di tahun tersebut, produksi beras Indonesia mengalami surplus sampai dengan 1,3 juta ton beras dan membuat Indonesia berhasil mencapai swasembada beras. Berkat prestasi tersebut, FAO memberikan penghargaan kepada Indonesia dalam bentuk bantuan sukarela untuk petani sebesar 100 ribu ton gabah [10].

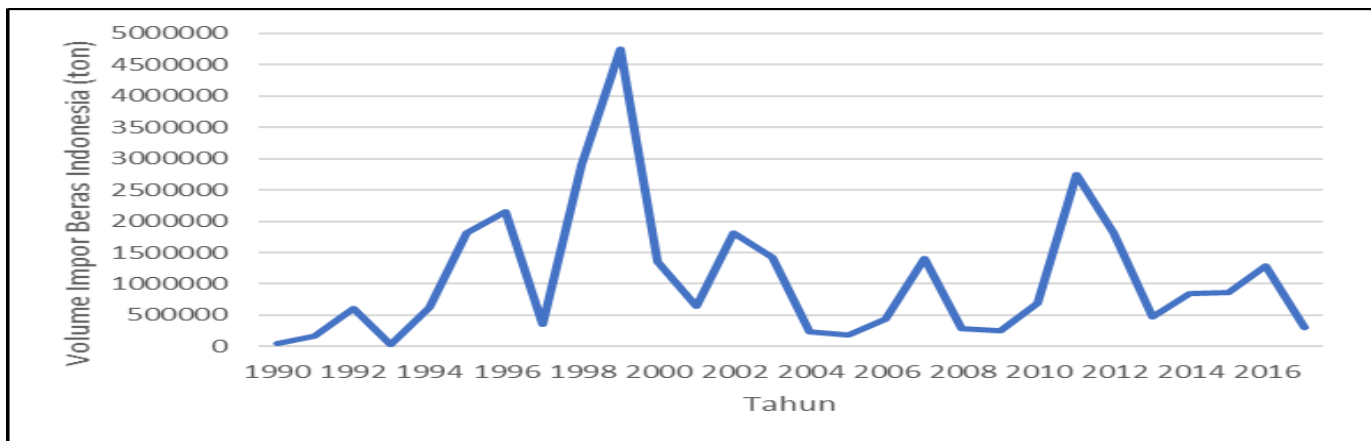

Gambar 1. Perkembangan Volume Impor Beras Indonesia 1990-2017 (Sumber : BPS) 


\section{Abyan Rai , Sasmito Hadi Wibowo}

Setelah mencapai swasembada beras di tahun 1984, volume impor beras Indonesia cenderung rendah. Meskipun demikian, Indonesia kesulitan untuk mengulangi capaian swasembada beras. Berdasarkan Gambar 1, volume impor Indonesia relatif rendah sampai dengan tahun 1993. Namun Indonesia gagal menjaga kestabilan produksi beras di tahun tersebut. Sehingga di tahun-tahun berikutnya volume impor beras Indonesia mengalami peningkatan yang cukup signifikan.

Secara umum, volume impor beras Indonesia sangat fluktuatif dari tahun 1990 sampai dengan tahun 2017. Impor beras terbanyak yang pernah dilakukan Indonesia selama periode tersebut terjadi di tahun 1998 dan 1999 dengan nilai volume impor beras mencapai 2,8 juta ton dan 4,75 juta ton. Hal ini disebabkan karena Indonesia mengalami krisis di tahun tersebut.

Di tahun 2005 dan 2009, Indonesia sempat memiliki volume impor beras yang rendah karena keberhasilan dalam mendorong peningkatan produksi beras. Namun, Indonesia kembali melakukan impor beras secara besar di tahun 2010 dan 2011. Hal ini merupakan dampak dari krisis yang dialami oleh Indonesia pada tahun 2008.

\subsection{Gambaran Umum Produksi Beras Indonesia}

Produksi beras Indonesia memiliki tren yang positif selama periode tahun 1993 sampai dengan tahun 2015. Rata-rata pertumbuhan produksi beras di Indonesia selama periode tersebut juga positif. Volume beras yang dihasilkan cenderung meningkat dibandingkan dengan periode sebelumnya dengan nilai pertumbuhan sebesar $2,1 \%$.

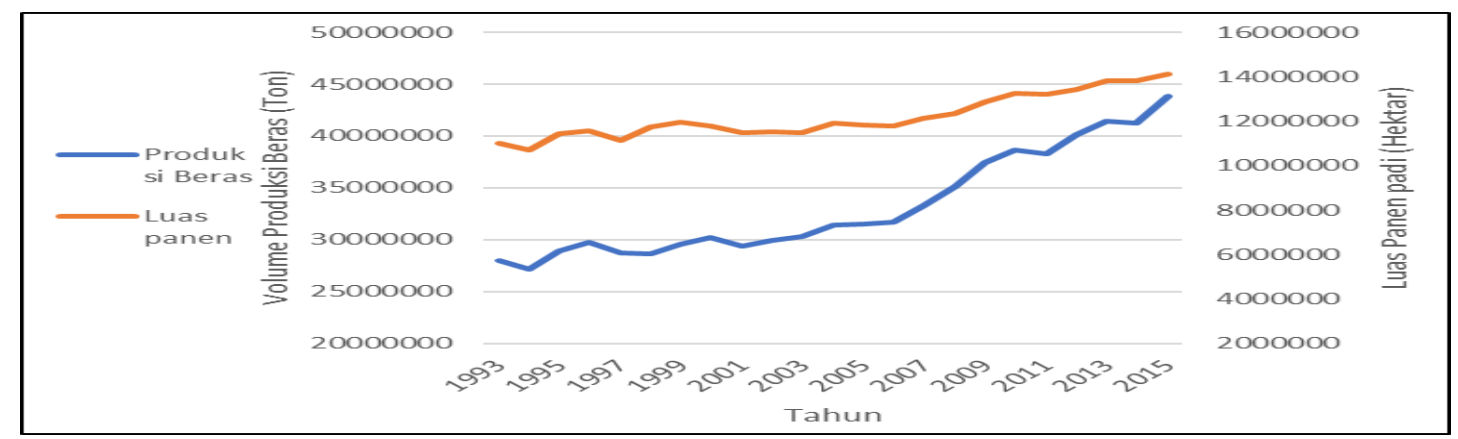

Gambar 2. Pergerakan Produksi Beras dan Luas Lahan Panen Padi 1993-2015 (Sumber: BPS)

Gambar 2 menunjukan bahwa penurunan yang paling masif terjadi pada tahun 1997 akibat adanya krisis ekonomi yang berdampak pada pencabutan subsidi pupuk dan bibit oleh pemerintah. Produksi beras Indonesia mengalami pertumbuhan yang stabil dan baik pada tahun 2006 sampai dengan tahun 2009. Produksi beras tertinggi yang dihasilkan Indonesia selama periode 1993 sampai dengan 2015 adalah pada tahun 2015 dengan volume beras yang diproduksi mencapai 43,8 juta ton. Secara keseluruhan, volume beras yang dihasilkan Indonesia mengalami pergerakan yang flutuatif.

Sama halnya dengan produksi beras Indonesia, luas lahan panen padi di Indonesia juga memiliki tren yang positif. Selama tahun 1993 sampai dengan 2015. Luas lahan panen padi Indonesia memiliki pertumbuhan yang positif dengan rata-rata pertumbuhan sebesar $1,17 \%$. Di tahun 2015, luas lahan panen padi Indonesia mencapai 14,1 juta hektar.

Berdasarkan Lampiran 1, impor beras yang dilakukan Indonesia sering kali terjadi saat produksi beras Indonesia sedang mengalami penurunan dan juga sebaliknya. Hal ini bisa terlihat di tahun 1994 saat produksi beras mengalami penurunan, pemerintah melakukan upaya pemenuhan konsumsi beras dengan melakukan impor beras di tahun tersebut. Di tahun 2007 


\section{Abyan Rai , Sasmito Hadi Wibowo}

sampai dengan tahun 2009, produksi beras mengalami peningkatan yang signifikan dan membuat Indonesia mengurangi impor beras di tahun tersebut.

Meskipun demikian, kenaikan produksi beras juga tidak selalu diikuti dengan penurunan volume impor beras. Hal ini terjadi pada saat Indonesia mengalami krisis ekonomi. Saat kondisi tersebut, impor beras dilakukan bukan hanya untuk memenuhi konsumsi beras masyarakat tetapi juga untuk menjaga harga beras tetap terjangkau.

\subsection{Gambaran Umum Harga Beras Impor dan Domestik}

Berdasarkan Lampiran 2, harga beras di Indonesia cenderung memiliki tren yang positif dari tahun 1990 sampai dengan tahun 2015. Rata-rata pertumbuhan harga beras Indonesia selama periode tersebut adalah 13,6\%. Lonjakan harga beras yang paling tinggi terjadi pada tahun 2005 sampai dengan tahun 2012. Di tahun 2013 sampai dengan 2017, pertumbuhan harga beras Indonesia relatif stabil. Harga beras Indonesia di tahun 2017 adalah 13224 rupiah per kilogram.

Upaya pemerintah untuk stabilisasi harga beras dengan melakukan impor beras dapat terlihat pada Lampiran 2. Indonesia melakukan impor beras yang sangat tinggi di tahun 1998 dan 1999 untuk menekan kenaikan harga beras yang tinggi sebagai dampak dari krisis ekonomi. Upaya tersebut berhasil menurunkan harga beras di Indonesia di tahun 1999 dan 2000. Keberhasilan upaya pemerintah melakukan impor beras untuk menurunkan harga juga terjadi di tahun 2002 dan 2003. Namun, upaya pemerintah di tahun 2008 dengan melakukan impor beras yang tinggi tidak efektif untuk menurunkan harga beras di Indonesia karena di tahun tersebut terjadi kenaikan harga pangan dunia.

Harga beras impor memiliki andil yang cukup besar dalam memengaruhi keputusan pemerintah Indonesia untuk melakukan impor beras. Harga beras impor yang relatif lebih murah akan memberikan tekanan terhadap harga beras domestik. Sehingga harga beras domestik tetap stabil dan terjangkau bagi masyarakat.

Meskipun demikian, Lampiran 3 menunjukkan bahwa kenaikkan harga impor sering kali juga diikuti dengan kenaikan impor beras. Peristiwa tersebut terjadi saat kondisi perekonomian Indonesia tidak dalam kondisi yang baik. Hal ini bisa dilihat pada tahun 1996 sampai dengan tahun 1999. Kejadian yang sama terulang kembali di tahun 2008 sampai dengan 2010.

\subsection{Hasil Uji Stasioneritas}

Data time series diasumsikan bersifat konstan dan independen dari waktu ke waktu. Apabila data time series tidak stasioner, regresi yang dihasilkan akan bersifat semu atau spurious [4]. Oleh karena itu, pengujian stasioneritas data diperlukan untuk menghindari hasil regresi yang bersifat semu. Data dikatakan stasioner jika varians dan rata-rata dari data tersebut konstan sepanjang waktu dan nilai kovarians antara dua periode waktu hanya bergantung pada lag antara kedua periode tersebut, bukan pada waktu aktual varians penghitungan [4].

Hipotesis null dari uji stasioner adalah data tidak bersifat stasioner. Tabel 1 menunjukan hasil dari pengujian stasioneritas data di level. Berdasarkan tabel tersebut, nilai probabilitas dari data produksi beras Indonesia, harga beras impor, dan harga beras domestik masih lebih besar dari tingkat alpha error 5\%. Artinya belum ditemukan cukup bukti untuk menyatakan bahwa data volume impor, harga beras impor, dan harga beras domestik sudah stasioner di level dengan tingkat alpha error 5\%. Sebaliknya, data volume impor beras Indonesia sudah memiliki nilai probabilitas kurang dari tingkat alpha error 5\%. Artinya, ada cukup bukti untuk menyatakan bahwa data volume impor beras Indonesia sudah stasioner di level dengan tingkat alpha error $5 \%$. 


\section{Abyan Rai , Sasmito Hadi Wibowo}

Tabel 1. Hasil Uji Stasioneritas Data

\begin{tabular}{|c|c|c|}
\hline \multirow{2}{*}{ Variabel } & \multicolumn{2}{|c|}{ P-Value } \\
\cline { 2 - 3 } & Level & First Difference \\
\hline$(1)$ & $(2)$ & $(3)$ \\
\hline Ln_X & 0.0031 & 0.0000 \\
\hline Ln_X & 0.982 & 0.0000 \\
\hline Ln_X & 0.26 & 0.0003 \\
\hline Ln_X & 0.9128 & 0.0000 \\
\hline
\end{tabular}

Karena berdasarkan pengujian stasioneritas di level menyimpulkan bahwa ada beberapa data yang belum stasioner di level, pengujian stasioneritas di difference pertama diperlukan. Tabel 1 menunjukan hasil dari pengujian stasioneritas untuk seluruh data penelitian di difference pertama. Berdasarkan tabel tersebut, nilai probabilitas untuk data volume impor beras Indonesia, produksi beras Indonesia, harga beras impor, dan harga beras Indonesia sudah lebih kecil bila dibandingkan dengan nilai alpha error 5\%. Dengan demikian, kesimpulan yang bisa ditarik adalah bahwa data volume impor beras Indonesia, produksi beras Indonesia, harga beras impor, dan harga beras Indonesia sudah stasioner di tingkat difference pertama dengan tingkat alpha error yaitu $5 \%$.

\subsection{Hasil Pemilihan Lag Optimum}

Pemilihan panjang lag merupakan prosedur yang sangat penting dalam analisis data time series, terutama analisis menggunakan metode VAR karena pengujian yang lain sangat sensitive terhadap panjang lag. Selain pertimbangan optimalitas, pemilihan panjang lag juga perlu mempertimbangkan adanya kemungkinan korelasi antar residual dan juga penurunan derajat bebas. Lag yang terlalu pendek akan menyebabkan korelasi serial muncul, sedangkan lag yang terlalu panjang akan mengakibatkan penurunan derajat bebas dan memperbanyak jumlah parameter yang harus diestimasi [3].

Berdasarkan lampiran 4, lag empat adalah lag yang terpilih berdasarkan kriteria dari FPE, AIC, SC, dan HQ. Jumlah lag optimum alternatif adalah jumlah lag satu karena memiliki nilai SC yang paling optimum di antara lag dua dan tiga. Selain itu, keterbatasan observasi membuat lag satu menjadi pilihan lag yang paling memungkinkan untuk mencapai model yang optimal. Dengan demikian, jumlah lag yang terpilih dalam penelitian ini adalah satu lag. Meskipun demikian, pengujia stabilitas VAR masih diperlukan untuk model dengan jumlah lag satu. Apabila model VAR tidak stabil, jumlah lag lain akan menjadi jumlah lag optimum terpilih dengan asumsi jumlah lag lain sudah stabil.

\subsection{Hasil Uji Stabilitas VAR}

Sistem VAR dapat dikatakan stabil apabila seluruh rootnya memiliki nilai modulus kurang dari satu. Lampiran 5 menunjukan bahwa pengujian stabilitas VAR menggunakan roots characteristic polynomial memberikan kesimpulan bahwa nilai modulus untuk seluruh roots sudah bernilai kurang dari satu. Artinya, model VAR yang dibangun dengan menggunakan satu lag sudah stabil. 


\section{Abyan Rai , Sasmito Hadi Wibowo}

\subsection{Hasil Uji Kointegrasi}

Dalam metode pengujian kointegrasi Johansen Cointegration, ada lima asumsi deterministik tren. Penelitian ini menggunakan asumsi adanya intersep baik dalam persamaan kointegrasi maupun persamaan VAR namun tidak ada tren baik di persamaan kointegrasi maupun di dalam persamaan VAR. Hal ini didasari oleh Gambar 1 yang menunjukan bahwa data volume impor beras Indonesia tidak memiliki tren tetapi memiliki intersep.

Hipotesis null dari uji kointegrasi adalah terdapat $\mathrm{r}$ persamaan kointegrasi dengan $\mathrm{r}$ adalah jumlah variabel dalam sistem $(\mathrm{r}=0,1, \ldots, \mathrm{n}-1)$ [7]. Lampiran 6 menunjukan hasil dari uji kointegrasi menggunakan statistik uji Trace. Tabel tersebut menunjukan hasil dari pengujian kointegrasi menggunakan statistik uji trace menyimpulkan bahwa terdapat satu persamaan kointegrasi. Artinya, antarvariabel penelitian memiliki kointegrasi berdasarkan hasil uji tersebut pada alpha error 5\%. Hal yang tidak berbeda juga ditunjukan oleh Lampiran 7. Berdasarkan tabel tersebut, persamaan kointegrasi antarvariabel adalah satu persamaan menggunakan statistik uji maximum eigen. Artinya, antarvariabel dalam penelitian memiliki persamaan kointegrasi dengan tingkat alpha error $5 \%$.

\subsection{Hasil Uji Asumsi}

Hipotesis null dari uji normalitas adalah bahwa eror dari model berdistribusi normal [4]. Berdasarkan Lampiran 8, persamaan satu, dua, dan empat di dalam VECM memiliki nilai probabilitas dari statistik jarque bera lebih besar dari 5\%. Dengan demikian, dapat disimpulkan bahwa hipotesis null gagal ditolak dengan tingkat alpha error 5\%. Artinya, asumsi normalitas untuk persamaan satu, dua, dan empat dalam model VECM yang dibentuk sudah terpenuhi. Persamaan tiga dan multivariat belum memenuhi asumsi normalitas. Hal tersebut akan mengurangi akurasi dari pengujian $\mathrm{t}$ dan $\mathrm{F}$. Meskipun demikian, hal tersebut tidak menjadi masalah karena penelitian ini berfokus pada persamaan satu dari model VECM (volume impor beras sebagai variabel dependen). Selain itu, asumsi normalitas tidak begitu esensial jika tujuan utama dalam penelitian hanya untuk melakukan estimasi [4].

Hipotesis null untuk uji autokorelasi adalah error di dalam model tidak saling berkorelasi [4]. Berdasarkan Lampiran 9, nilai probabilitas dari statistik lagrange multiplier untuk lag pertama sampai dengan lag ke-4 tidak ada yang lebih kecil dari 5\%. Dengan demikian, kesimpulan yang dapat diambil adalah bahwa tidak ditemukan cukup bukti untuk menolak hipotesis null. Artinya, asumsi nonautokorelasi untuk model VECM dalam penelitian ini sudah terpenuhi sampai dengan lag ke-4.

\subsection{Estimasi Persamaan Jangka Panjang dan VECM Impor Beras Indonesia}

Hubungan jangka panjang dari variabel di dalam penelitian terhadap volume impor beras Indonesia dapat dituliskan dalam persamaan sebagai berikut:

$$
\widehat{L n_{X 1_{t}}}=-21,50647-5,917^{*} L n_{X 2_{t}}-1,086 \operatorname{Ln}_{\mathrm{X} 3_{t}}+2,152^{*} L n_{\mathrm{X} 4_{t}}
$$

$$
\text { S.E. }
$$

Keterangan: *signifikan pada alpha $10 \%$

Berdasarkan persamaan tersebut, produksi beras Indonesia memiliki pengaruh negatif terhadap volume impor beras Indonesia. Pengaruh tersebut tidak signifikan untuk tingkat alpha error 5\%. Namun, pengaruh tersebut merupakan pengaruh yang signifikan dengan tingkat alpha error sebesar $10 \%$. Semakin besar volume beras yang dihasilkan, semakin kecil impor beras yang dilakukan.

Dalam jangka panjang, produksi beras Indonesia mengalami tren yang positif seperti yang tergambar dalam analisis deksripsi. Hal tersebut membuat volume impor beras Indonesia 


\section{Abyan Rai , Sasmito Hadi Wibowo}

berkurang. Hasil ini sesuai dengan penelitian terdahulu bahwa produksi beras memiliki pengaruh signifikan yang negatif terhadap volume impor beras [11].

Harga beras impor memberikan pengaruh negatif terhadap volume impor beras Indonesia. Semakin mahal harga beras impor akan semakin sedikit beras yang diimpor oleh Indonesia. Meskipun demikian, pengaruh yang diberikan oleh harga beras impor terhadap volume impor beras Indonesia tidak signifikan. Hal ini bisa terjadi karena permintaan volume impor beras Indonesia tidak elastis terhadap harga beras impor. Perubahan harga beras impor hanya diikuti perubahan permintaan impor beras yang relatif kecil.

Harga beras domestik memberikan pengaruh positif terhadap volume impor beras Indonesia. Pengaruh tersebut signifikan pada tingkat alpha error $10 \%$. Semakin mahal harga beras di dalam negeri, semakin tinggi permintaan Indonesia terhadap beras impor sebagai respons untuk menyetabilkan harga beras domestik.

Dalam teori pemintaan, harga beras domestik dengan harga beras impor bersifat substitusi [13]. Sehingga, kenaikan harga beras domestik yang membuat beras domestik menjadi relatif lebih mahal di pasar akan meningkatkan permintaan terhadap beras impor. Hal ini sesuai dengan penelitian yang dilakukan oleh Armaini dan Gunawan (2016) yang menyimpulkan bahwa harga beras domestik memberikan pengaruh positif yang signifikan terhadap volume impor beras Indonesia.

Tabel 2. Persamaan VECM Volume Impor Beras Indonesia

\begin{tabular}{|c|c|c|c|c|}
\hline \multicolumn{5}{|c|}{ Dependend Variabel = D(LN_X1) } \\
\hline Lag & $\mathrm{D}\left(\mathrm{LN} \_\mathrm{X} 1\right)$ & $\mathrm{D}\left(\mathrm{LN} \_\mathrm{X} 2\right)^{*}$ & $\mathrm{D}\left(\mathrm{LN} \_\mathrm{X} 3\right)$ & $\mathrm{D}\left(\mathrm{LN} \_\mathrm{X} \$\right)^{*}$ \\
\hline (1) & (2) & (3) & (4) & (5) \\
\hline \multirow{2}{*}{1} & -0.184648 & -19.33149 & -1.151137 & 5.040398 \\
\hline & {$[-1.06342]$} & {$[-3.46884]$} & {$[-1.39860]$} & {$[2.53505]$} \\
\hline \multicolumn{2}{|c|}{ Konstanta } & $\begin{array}{l}58 \\
9]\end{array}$ & $\begin{array}{r}=-0,678 \\
{[-3,82]}\end{array}$ & \\
\hline
\end{tabular}

Berdasarkan Tabel 2, volume impor beras saat ini dipengaruhi secara negatif oleh lag dari volume impor beras itu sendiri dalam jangka pendek. Meskipun demikian, lag dari volume impor beras tidak memberikan pengaruh yang signifikan terhadap volume impor beras saat ini. Keputusan untuk melakukan impor di tahun mendatang tidak berhubungan dengan volume beras yang diimpor pada saat ini.

Produksi beras periode sebelumnya memberikan pengaruh yang negatif terhadap volume impor beras Indonesia dalam jangka pendek. Produksi beras pada satu tahun sebelumnya memberikan pengaruh yang signifikan terhadap volume impor beras Indonesia dengan tingkat alpha error $5 \%$. Jika perubahan produksi beras satu tahun sebelumnya naik $1 \%$, perubahan volume impor beras menurun sebesar 19,33\%. Hasil ini menjadi dorongan terhadap pemerintah untuk meningkatkan volume produksi beras nasional agar mampu menekan ketergantungan negara terhadap impor beras.

Sementara itu, pengaruh dari harga beras impor terhadap volume impor beras Indonesia dalam jangka pendek sejalan dengan pengaruhnya dalam jangka panjang. Harga beras pada tahun-tahun sebelumnya memberikan pengaruh yang negatif terhadap volume impor beras Indonesia saat ini dalam jangka pendek. Meskipun demikian, pengaruh tersebut bukan merupakan pengaruh yang signifikan. Hal ini bisa terjadi karena harga beras lokal dari negara pengekspor beras ke Indonesia relatif stabil. Selain itu, hasil ini juga mengindikasikan bahwa volume impor beras Indonesia tidak elastis terhadap harga beras impor. 


\section{Abyan Rai , Sasmito Hadi Wibowo}

Harga beras domestik pada tahun sebelumnya memberikan pengaruh positif terhadap volume impor beras Indonesia saat ini dalam jangka pendek, sejalan dengan pengaruhnya dalam jangka panjang. Harga beras domestik satu tahun sebelumnya memberikan pengaruh signifikan terhadap volume impor beras Indonesia saat ini dengan tingkat alpha error 5\%. Jika perubahan harga beras domestik satu tahun sebelumnya meningkat $1 \%$, perubahan volume impor beras Indonesia meningkat $5,04 \%$.

Rendahnya surplus produksi beras Indonesia terhadap konsumsi beras Indonesia yang bahkan cenderung defisit di tahun t membuat stok beras Indonesia tidak bisa terisi oleh produksi beras domestik. Dampaknya adalah kenaikan harga beras domestik di tahun t. Kenaikan harga tersebut perlu dikendalikan dengan melakukan menaikkan volume impor beras Indonesia untuk mengisi stok beras Indonesia di tahun $\mathrm{t}+1$. Sehingga harga beras domestik menjadi stabil. Hal ini sesuai dengan penelitian terdahulu bahwa harga beras domestik memiliki pengaruh terhadap volume impor beras Indonesia [9].

Nilai ECT untuk persamaan VECM volume impor beras Indonesia memiliki nilai koefisien negatif sebesar -0,67 dan signifikan pada tingkat alpha error 5\%. Tanda negatif pada koefisien tersebut menunjukkan bahwa saat terjadi ketidakseimbangan, koreksi akan dilakukan menuju keseimbangan pada periode selanjutnya. Nilai 0,67 menunjukkan bahwa ketidakseimbangan pada periode sebelumnya terkoreksi sebesar $67 \%$ pada saat ini. Sementara itu, 33\% sisanya akan dikoreksi pada periode-periode selanjutnya.

\subsection{Hubungan Kausalitas Volume Impor Beras Indonesia Dengan Produksi Beras, Harga \\ Beras Impor, dan Harga Beras Domestik}

Pengujian kausalitas granger dilakukan untuk mengetahui hubungan timbal balik dari variabel produksi beras, harga beras impor, dan harga beras domestik terhadap volume impor beras Indonesia. Hasil dari pengujian tersebut menunjukkan bahwa beberapa variabel penelitan memiliki hubungan yang searah dengan volume impor beras Indonesia. Sedangkan beberapa yang lain memiliki hubungan dua arah.

Hipotesis null dari uji granger adalah variabel independen tidak berpengaruh secara signifikan terhadap variabel dependen [4]. Tabel 3 menunjukkan hubungan dari produksi beras, harga beras impor, dan harga beras domestik dengan volume impor beras Indonesia. Produksi beras secara signifikan berpengaruh terhadap volume impor beras Indonesia pada tingkat alpha error 5\%. Harga beras domestik juga memberikan pengaruh yang signifikan terhadap volume impor beras Indonesia pada tingkat alpha error 5\%. Sedangkan, harga beras impor tidak memberikan pengaruh yang signifikan terhadap volume impor beras Indonesia. Hasil ini sejalan dengan hasil estimasi jangka pendek VECM.

Tabel 3. Hasil Uji Hubungan Kausalitas Antar Variabel

\begin{tabular}{|l|c|c|c|}
\hline \multicolumn{1}{|c|}{ Variabel } & Chisq-stat & Df & Prob \\
\hline $\mathrm{D}\left(\mathrm{LN} \_X 2\right) \rightarrow \mathrm{D}\left(\mathrm{LN} \_X 1\right)^{*}$ & 12.03287 & 1 & 0.0005 \\
$\mathrm{D}\left(\mathrm{LN} \_\mathrm{X} 1\right) \rightarrow \mathrm{D}\left(\mathrm{LN} \_\mathrm{X} 2\right)^{*}$ & 7.58577 & 1 & 0.0059 \\
\hline $\mathrm{D}\left(\mathrm{LN} \_\mathrm{X} 4\right) \rightarrow \mathrm{D}\left(\mathrm{LN} \_\mathrm{X} 1\right)^{*}$ & 6.426482 & 1 & 0.0112 \\
$\mathrm{D}\left(\mathrm{LN} \_\mathrm{X} 1\right) \rightarrow \mathrm{D}\left(\mathrm{LN} \_\mathrm{X} 4\right)$ & 0.057351 & 1 & 0.8107 \\
\hline $\mathrm{D}(\mathrm{LN}) \mathrm{X} 3) \rightarrow \mathrm{D}\left(\mathrm{LN} \_\mathrm{X} 1\right)$ & 1.95607 & 1 & 0.1619 \\
$\mathrm{D}\left(\mathrm{LN} \_\mathrm{X} 1\right) \rightarrow \mathrm{D}\left(\mathrm{LN} \_\mathrm{X} 3\right)$ & 0.918061 & 1 & 0.338 \\
\hline
\end{tabular}

Keterangan: *signifikan pada alpha 5\% 


\section{Abyan Rai , Sasmito Hadi Wibowo}

Sementara itu, volume produksi secara signifikan dipengaruhi oleh volume impor beras Indonesia pada tingkat alpha error 5\% berdasarkan hasil uji kausalitas granger. Namun, hal yang serupa tidak terjadi pada harga beras domestik yang tidak dipengaruhi secara signifikan oleh volume impor beras Indonesia berdasarkan hasil uji kausalitas granger. Harga beras impor juga tidak dipengaruhi secara signifikan oleh volume impor beras Indonesia berdasarkan hasil uji kausalitas granger.

Hasil estimasi yang ditampilkan pada Lampiran 13 menunjukkan bahwa lag dari volume impor beras Indonesia berpengaruh positif terhadap volume produksi beras secara signifikan dengan tingkat alpha error 5\%. Hal ini mungkin bisa terjadi karena ketika volume impor naik supply beras meningkat di tahun t. Karena supply beras di tahun t meningkat, permintaan impor beras di tahun $t+1$ menurun. Penurunan permintaan impor beras di tahun $t+1$ menjadi insentif petani untuk menaikkan produksi beras. Sehingga, terjadi peningkatan volume produksi beras di Indonesia.

Hubungan dua arah dari volume impor beras Indonesia dan volume produksi beras menggambarkan bahwa kedua variabel tersebut memang saling memengaruhi satu sama lain. Penurunan produksi beras memicu peningkatan volume impor beras Indonesia untuk mencukupi kebutuhan beras penduduk Indonesia. Di sisi lain, peningkatan supply beras akibat impor berdampak pada menurunnya permintaan impor beras di tahun berikutnya dan menjadi insentif bagi petani untuk meningkatan produksi beras dalam negeri di tahun berikutnya.

Hubungan satu arah terjadi antara volume impor beras Indonesia dan harga beras domestik. Peningkatan harga beras domestik mendorong pemerintah untuk melakukan stabilitas harga beras domestik. Salah satu instrumen yang digunakan untuk menyetabilkan harga beras domestik adalah dengan melakukan impor beras. Meskipun demikian, pengaruh dari volume impor beras Indonesia tidak signifikan terhadap penurunan harga beras domestik. Hal ini bisa disebabkan oleh banyaknya instrumen lain yang lebih berpengaruh terhadap harga beras domestik seperti volume produksi beras.

\subsection{Respons Volume Impor Beras Indonesia Terhadap Shock Produksi Beras dan Harga \\ Beras Domestik}

Respons dari volume impor beras saat produksi beras Indonesia mengalami shock cenderung negatif. Lampiran 10 menunjukkan bahwa pada periode pertama, shock dari produksi beras Indonesia direspons sedikit positif oleh volume impor beras Indonesia. Respons negatif dari volume impor beras mulai muncul pada periode ke-2 sampai periode ke-3 dengan perubahan sebesar $-0,64 \%$ dan $-0,201 \%$. Shock dari produksi beras Indonesia menimbulkan fluktuasi jangka panjang hingga pada periode ke-17 relatif stabil pada perubahan sebesar $-0,02 \%$.

Respons dari volume impor beras Indonesia terhadap shock harga beras domestik ditunjukkan oleh Lampiran 11. Gambar tersebut memperlihatkan bahwa di periode pertama volume impor beras Indonesia langsung merespons shock dari harga beras domestik. Penigkatan terjadi secara signifikan pada periode ke-2 dengan nilai sebesar $0,51 \%$. Tahun-tahun selanjutnya, respons dari volume impor beras Indonesia terhadap harga beras domestik cenderung positif. Respons dari volume impor beras Indonesia cenderung stabil pada periode ke-13 dengan nilai perubahan sebesar $0,22 \%$. 


\section{Abyan Rai , Sasmito Hadi Wibowo}

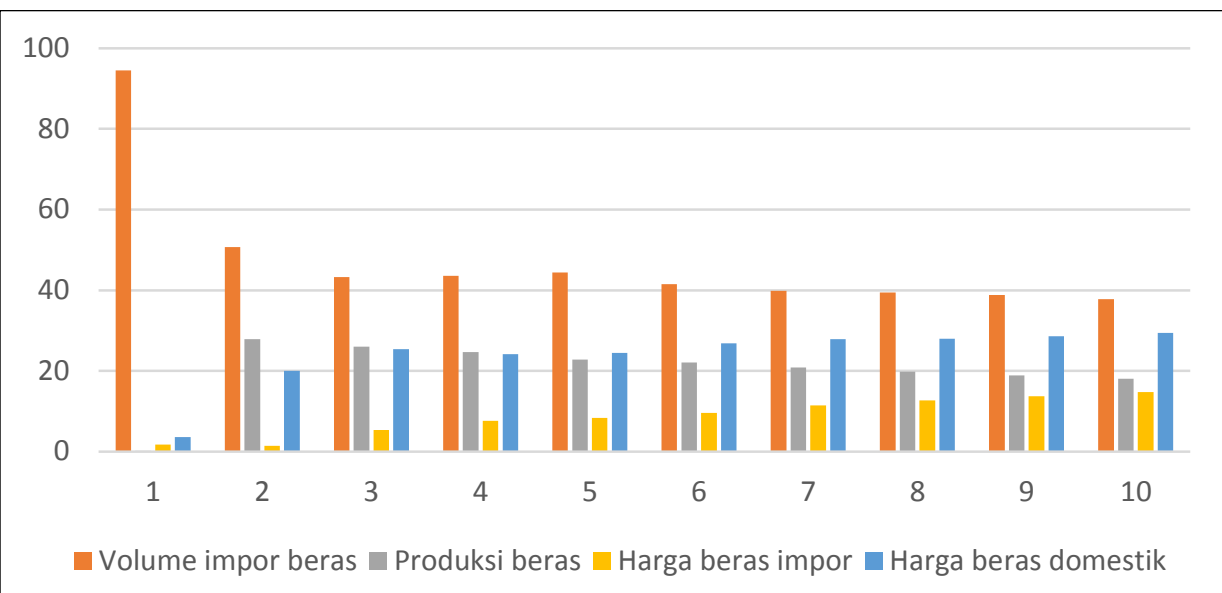

Gambar 3. Hasil Dekomposisi Varians Volume Impor Beras Indonesia

Gambar 3 menunjukkan dekomposisi varians dari volume impor beras Indonesia. Berdasarkan gambar tersebut, periode pertama dari variabilitias volume impor beras Indonesia didominasi oleh shock dari volume impor beras itu sendiri. Mulai periode ke-2, peran dari shock variabel lain mulai muncul terhadap variabilitas dari volume impor beras Indonesia meskipun variabel impor beras itu sendiri masih dominan.

Pada periode ke-2, produksi beras memiliki peranan yang lebih besar dengan 28,55\% dibandingkan harga beras domestik dengan 15,89\% terhadap variabilitas dari volume impor beras Indonesia. Pada periode ke-7, harga beras domestik memiliki peran yang lebih besar dari produksi beras. Di periode ke-10, variabel yang berperan paling dominan terhadap variabilitas volume impor beras Indonesia adalah volume impor beras Indonesia itu sendiri disusul dengan produksi bersa Indonesia dengan 47,05\%.

\subsection{Respons Produksi Beras Terhadap Shock Volume Impor Beras Indonesia}

Lampiran 12 menunjukkan bahwa respons dari produksi beras terhadap shock dari volume impor beras Indonesia tidak merespons pada periode pertama. Namun, peningkatan yang sangat signifikan terjadi pada periode ke-2 dengan perubahan sebesar $0,0077 \%$. Di tahun-tahun selanjutnya, respons dari produksi beras cenderung negatif sampai relatif stabil di periode ke-13 dari shock volume impor beras Indonesia dengan perubahan sebesar $-0,001687 \%$.

\section{Kesimpulan dan Saran}

\subsection{Kesimpulan}

Berdasarkan hasil penelitian, kesimpulan yang diperoleh adalah sebagai berikut:

1. Volume impor beras Indonesia memiliki pergerakan yang fluktuatif, sedangkan produksi beras, harga beras impor, dan harga beras domestik memiliki tren yang positif. Impor beras Indonesia umumnya dilakukan pada saat produksi beras sedang menurun dan harga beras domestik sedang meningkat.

2. Analisis deskriptif belum mampu menunjukan hubungan impor beras Indonesia dengan produksi beras, harga beras impor, dan harga beras domestik secara signifikan.

3. Volume impor beras Indonesia memiliki hubungan dua arah dengan produksi beras, sedangkan satu arah pada saat dipengaruhi oleh harga beras domestik. 


\section{Abyan Rai , Sasmito Hadi Wibowo}

4. Volume impor beras Indonesia memberikan respons yang negatif pada saat produksi beras mengalami shock dan respons yang positif pada saat harga beras domestik mengalami shock.

5. Produksi beras Indonesia memberikan respons yang negatif pada saat volume impor beras Indonesia mengalami shock.

\subsection{Saran}

Berdasarkan kesimpulan yang sudah diperoleh, saran yang bisa diberikan dari penelitian ini adalah sebagai berikut:

1. Kebijakan impor beras akan lebih baik jika didasari oleh produksi beras Indonesia mengingat impor beras memiliki hubungan dua arah dengan produksi beras. Impor beras yang dilakukan saat produksi sedang tinggi akan menurunkan produksi beras di periode mendatang berdasarkan kesimpulan poin ke-5.

2. Penelitian selanjutnya bisa menggunakan data produksi beras dengan metode yang terbaru yaitu Kerangka Sampel Area (KSA) yang bersifat lebih objektif.

\section{Daftar Pustaka}

[1] Christianto, E., 2013. Faktor Yang Mempengaruhi Impor Beras di Indonesia. Jurnal Jibeka, 7(2), hal. 38-43

[2] Djaenudinm, S., 2018. Impor beras berdampak negatif ke jutaan petani. Sumber: https://ekbis.sindonews.com/read/1342020/34/impor-beras-berdampak-negatif-ke-jutaanpetani-1538115174, diakses tanggal 24 Juni 2019.

[3] Enders, W., 2015. Applied Econometrics Time Series Fourth Edition. New York: John Wiley and Sons, Inc.

[4] Gujarati, D.N. dan Porter, D.C., 2008. Basic Econometrics Fifth Edition. New York: McGraw-Hill, Inc.

[5] Hermanto., 2012. Masyarakat Indonesia makan beras 139kg/orang/tahun. Sumber: http://bangka.tribunnews.com/2012/10/31/masyarakat-indonesia-makan-beras-139kgorangtahun, diakses tanggal 19 November 2018

[6] Ikhsan, M., 2001. Kemiskinan dan harga beras. hal. 173-209. Dalam A. Suryana dan S. Mardianto. Bunga Rampai Ekonomi Beras. Jakarta: LPEM-Fakultas Ekonomi Universitas Indonesia.

[7] Juanda, B. dan Junaidi., 2012. Ekonometrika Deret Waktu Teori dan Aplikasi. Bogor: IPB Press.

[8] Muchlisin, Z.A. dan Azizah, M.N., 2009. Diversity and Distribution of Freshwater Fishes in Aceh Water, Northern Sumatera, Indonesia. Academic Journal, 5(2), hal. 62-79.

[9] Namira, Y., Nuhung, L.A., dan Najamuddin, M., 2016. Analisis Faktor-Faktor Yang Mempengaruhi Impor Beras di Indonesia. Jurnal Agribisnis, 10, hal. 1.

[10] Pratomo, H.B., 2015. Di era Soeharto, petani Indonesia menjadi penyumbang pangan dunia. Sumber: http://www.merdeka.com, diakses tanggal 27 Maret 2019.

[11] Rungkat, M.D., 2014. Analisis Faktor-Faktor Yang Mempengaruhi Impor Beras di Sulawesi Utara. Jurnal Ilmiah Fakultas Pertanian Universitas Sam Ratulangi, 4, hal. 2. 


\section{Abyan Rai , Sasmito Hadi Wibowo}

[12] Suhariyanto., 2018. Jusuf Kalla sampaikan hasil KSA. Sumber: http://www.bps.go.id/news/2018/10/24/245/jk-sampaikan-hasil-ksa.html, diakses tanggal 27 Maret 2019.

[13] Sukirno, S., 2006. Makroekonomi Teori Pengantar Edisi Ketiga. Jakarta: PT Raja Grafindo Perkasa.

[14] Wibowo, S.H., 2005. BPS usul keran impor beras dibuka. Sumber: http://koran.tempo.co/read/50167/bps-usul-keran-impor-beras-dibuka, diakses tanggal 21 Mei 2019.

\section{Lampiran}

Lampiran 1. Perkembangan Produksi dan Volume Impor Indonesia Tahun 1993-2015

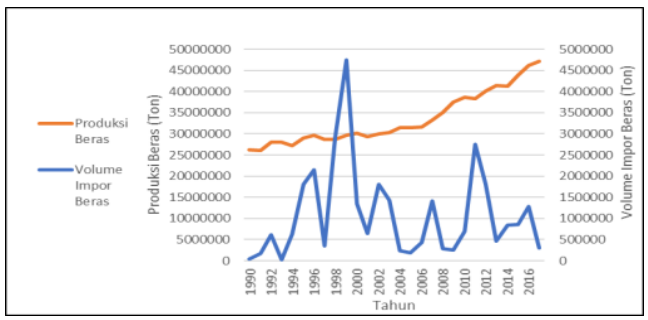

Lampiran 2. Perkembangan Harga dan Volume Impor Indonesia 1990-2017

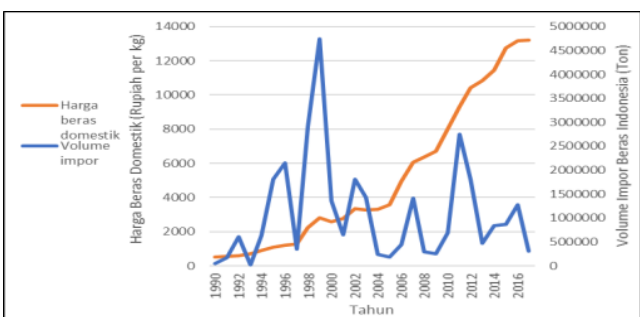

Lampiran 3. Pergerakan Harga Impor dan Volume Impor Tahun 1990-2017

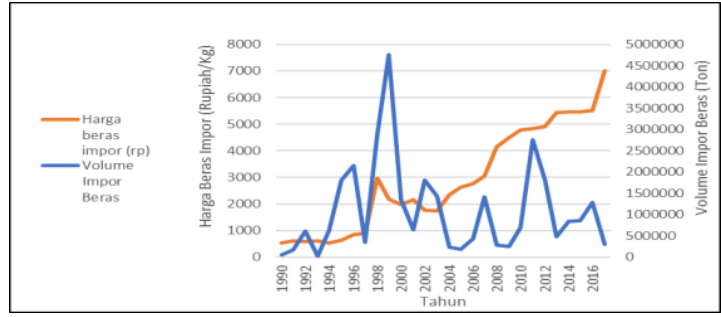

Lampiran 4. Hasil Pengujian Lag Optimum

\begin{tabular}{|c|c|c|c|c|c|c|}
\hline Lag & LogL & LR & FPE & AIC & SC & HQ \\
\hline$(1)$ & $(2)$ & $(3)$ & $(4)$ & $(5)$ & $(6)$ & $(7)$ \\
\hline 0 & -22.1 & NA & $1.03 \mathrm{E}-04$ & 2.17 & 2.37 & 2.22 \\
\hline 1 & 62.6 & 133.99 & $3.47 \mathrm{E}-07$ & -3.55 & -2.57 & -3.29 \\
\hline 2 & 87.9 & 31.69 & $1.81 \mathrm{E}-07$ & -4.33 & -2.56 & -3.86 \\
\hline
\end{tabular}




\section{Abyan Rai , Sasmito Hadi Wibowo}

\begin{tabular}{|c|c|c|c|c|c|c|}
\hline 3 & 109.5 & 19.82 & $1.63 \mathrm{E}-07$ & -4.79 & -2.24 & -4.12 \\
\hline 4 & 158.48 & $28.55^{*}$ & $2.54 \mathrm{e}-08^{*}$ & $-7.540^{*}$ & $-4.202 *$ & $-6.655^{*}$ \\
\hline
\end{tabular}

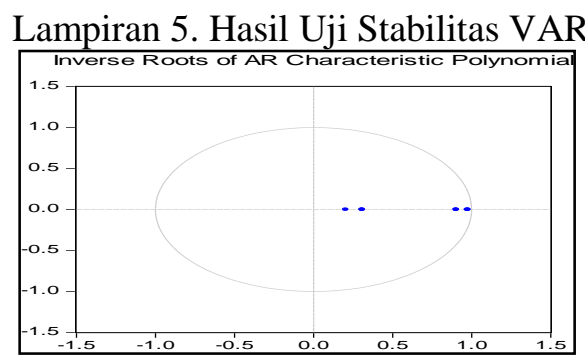

Lampiran 6. Hasil Uji Kointegrasi Menggunakan Statistik Uji Trace

\begin{tabular}{|c|c|c|c|c|}
\hline Hipotesis nol jumlah persamaan kointegrasi & Nilai eigen & Trace-stat & $\begin{array}{c}0.05 \text { Titik } \\
\text { Kritis }\end{array}$ & Prob \\
\hline$(1)$ & $(2)$ & $(3)$ & $(4)$ & $(5)$ \\
\hline Tidak ada* & 0.707712 & 48.88654 & 47.85613 & 0.0399 \\
\hline Paling banyak 1 & 0.328966 & 16.90615 & 29.79707 & 0.647 \\
\hline Paling banyak 2 & 0.211983 & 6.533811 & 15.49471 & 0.6324 \\
\hline Paling banyak 3 & 0.01298 & 0.33968 & 3.841466 & 0.56 \\
\hline
\end{tabular}

Lampiran 7. Hasil Uji Kointegrasi Menggunakan Statistik Uji Maximum Eigen

\begin{tabular}{|c|c|c|c|c|}
\hline $\begin{array}{c}\text { Hipotesis jumlah persamaan } \\
\text { kointegrasi }\end{array}$ & $\begin{array}{c}\text { Nilai } \\
\text { eigen }\end{array}$ & $\begin{array}{c}\text { MaxEigen- } \\
\text { stat }\end{array}$ & $\begin{array}{c}0.05 \text { Titik } \\
\text { Kritis }\end{array}$ & Prob \\
\hline$(1)$ & $(2)$ & $(3)$ & $(4)$ & $(5)$ \\
\hline Tidak ada* & 0.708 & 31.98 & 27.58 & 0.0127 \\
\hline Paling banyak 1 & 0.329 & 10.37 & 21.13 & 0.7091 \\
\hline Paling banyak 2 & 0.212 & 6.19 & 14.26 & 0.5884 \\
\hline Paling banyak 3 & 0.013 & 0.34 & 3.84 & 0.56 \\
\hline
\end{tabular}

Lampiran 8. Hasil Uji Normalitas

\begin{tabular}{|c|c|c|c|}
\hline Persamaan & Stat Jarque-Bera & df & Prob \\
\hline$(1)$ & $(2)$ & $(3)$ & $(4)$ \\
\hline 1 & 4,525756 & 2 & 0,1041 \\
\hline 2 & 0,097692 & 2 & 0,9523 \\
\hline 3 & 47,84086 & 2 & 0,0000 \\
\hline 4 & 0,719463 & 2 & 0,6979 \\
\hline Joint & 53,18377 & 8 & 0,0000
\end{tabular}

Lampiran 9. Hasil Uji Nonautokorelasi

\begin{tabular}{|c|c|c|}
\hline Lag & LM-stat & Prob* \\
\hline$(1)$ & $(2)$ & $(3)$ \\
\hline 1 & 17.68987 & 0.3424 \\
\hline 2 & 15.87081 & 0.462 \\
\hline 3 & 16.68157 & 0.4065 \\
\hline 4 & 14.17949 & 0.5853 \\
\hline
\end{tabular}




\section{Abyan Rai , Sasmito Hadi Wibowo}

Lampiran 10. Respons Volume Impor Beras Terhadap shock Produksi beras

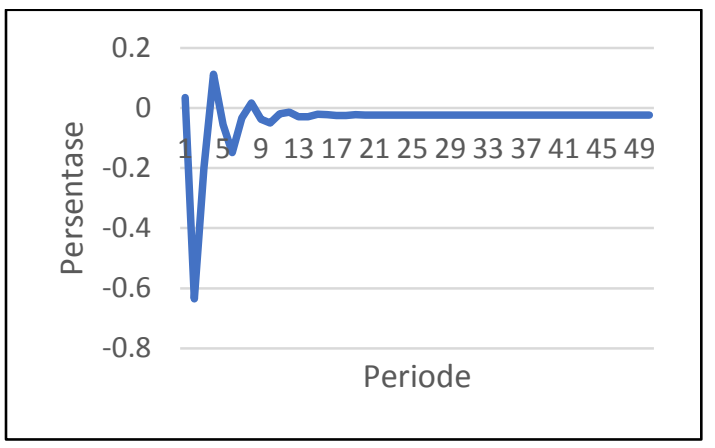

Lampiran 11. Respons Volume Impor Beras Terhadap shock Harga Beras Domestik

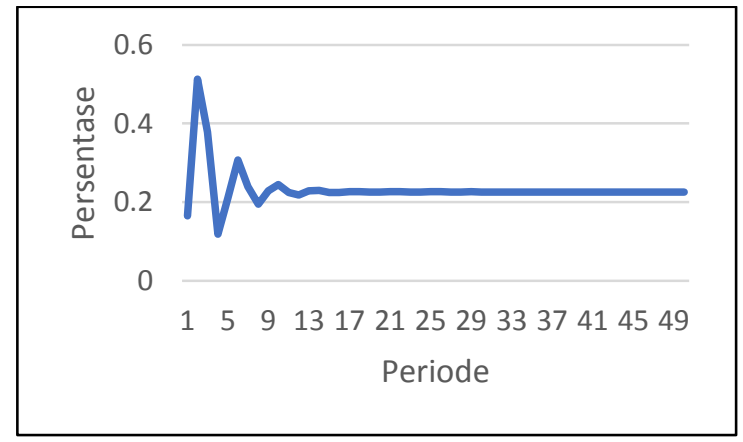

Lampiran 12. Respons Produksi Beras Terhadap Shock Volume Impor Beras

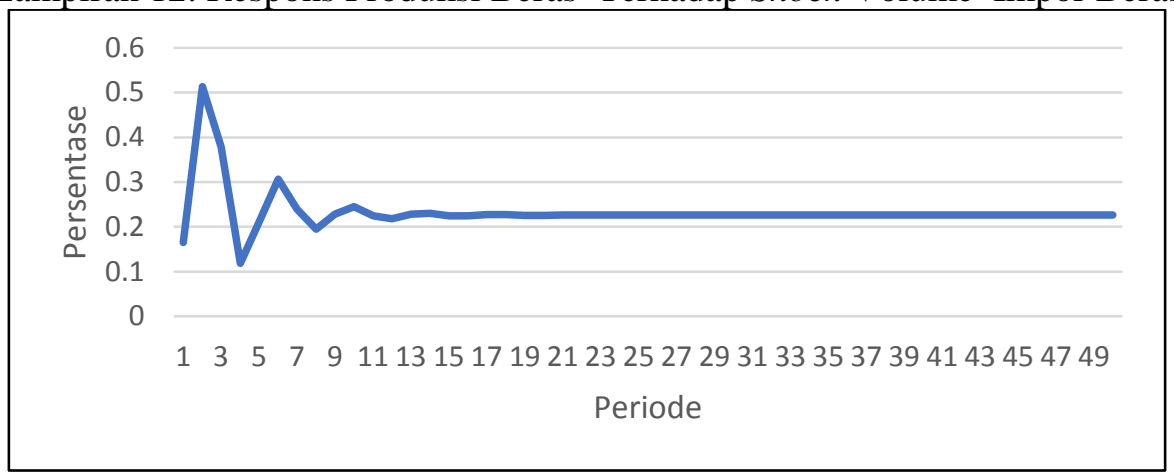

Lampiran 13. Persamaan VECM Produksi Beras

\begin{tabular}{|c|c|c|c|c|}
\hline \multicolumn{5}{|c|}{ Dependend Variabel = LN_Prod } \\
\hline Lag & D(LN_Volimp) & D(LN_Prod) & D(LN_HBIRP) & D(LN_HBD) \\
\hline$(1)$ & $(2)$ & $(3)$ & $(4)$ & $(5)$ \\
\hline 1 & 0.0159 & -0.041 & 0.0003 & -0.03 \\
\hline
\end{tabular}

